\title{
In vitro effects of relaxin on gene expression in porcine cumulus-oocyte complexes and developing embryos
}

\author{
Jean M Feugang ${ }^{1 *}$, Jonathan M Greene ${ }^{1}$, Scott T Willard ${ }^{2}$, Peter L Ryan ${ }^{1,3^{*}}$
}

\begin{abstract}
Background: Relaxin hormone peptide is found in porcine follicular and utero-tubal fluids, but its possible actions during early embryo development are still undetermined. Here, we investigated the effects of porcine relaxin during oocyte maturation and embryo development, and gene expression in the pig.

Methods: Immature cumulus-oocyte complexes (COCs) were obtained from ovarian follicles of sows. In experiment 1 , COCs were matured in the presence of 0,20 , or $40 \mathrm{ng}$ relaxin/ml, or $10 \%(\mathrm{v} / \mathrm{v})$ porcine follicular fluid. In experiment 2, COCs were in vitro matured, fertilized and resulting embryos were cultured in the presence of 0, 20, or $40 \mathrm{ng}$ relaxin/ml. In experiment 3, COCs were matured in the presence of $40 \mathrm{ng}$ relaxin/ $\mathrm{ml}$, fertilized and zygotes were cultured as indicated in experiment 2. We evaluated the proportions of matured oocytes in experiment 1, cleaved and blastocysts on Day 2 and Day 7 post insemination in all experiments. The total cell number of blastocysts was also evaluated. In parallel, transcription levels of both relaxin and its receptors (RXFP1 and RXFP2), as well as a pro- (Bax) and anti- (Bcl2-like 1) apoptotic-related genes were determined. All data were analyzed by ANOVA and significant differences were fixed for $\mathrm{P}<0.05$.
\end{abstract}

Results: In experiment 1, relaxin significantly increased the proportions of matured oocytes and cleaved embryos, as well as the expression level of RXFP2 mRNA compared to RXFP1 $(P<0.05)$. There was no effect on endogenous expression of relaxin and Bcl2-like1/Bax ratios. In all experiments, relaxin did not affect the proportions of blastocysts, but did significantly increase their total cell numbers $(P<0.05)$. Furthermore, no effect of relaxin was observed on Bcl2-like1/Bax expression ratios, which were similar between groups.

Conclusions: Exogenous relaxin influences its own receptors expression, improves oocyte nuclear maturation. Its beneficial effect on total cell number of blastocysts appears to be through a Bcl2-like1/Bax-independent mechanism.

\section{Background}

Gene expression is one of the major events occurring during oocyte maturation and early embryo development, and its perturbation in culture system may contribute to the limited production of high quality blastocysts [1-3]. Numerous strategies such as low oxygen tension during culture, co-culture, and utilization of simple or complex media supplemented with various molecules have been developed to improve embryo culture efficiencies [1,4-6]. These molecules such as relaxin

\footnotetext{
* Correspondence: jn181@ads.msstate.edu; pryan@provost.msstate.edu 'Department of Animal \& Dairy Sciences, Mississippi State University, 4025 Wise Center Dr, Mississippi State, MS 38762, USA

Full list of author information is available at the end of the article
}

are generally found in the vicinity of oocytes and embryos. Relaxin is a peptide hormone found at higher levels in follicular fluids and genital tract secretions of various species [7-11]. Despite its pleiotropic roles reported in various reproductive and non-reproductive tissues [11-13], little is still known on embryonic effects of relaxin during early pregnancy.

In livestock, the pig is the primary animal model used for the study of relaxin effects $[11,14,15]$ due to the important production of relaxin in both pregnant and non-pregnant pigs. Indeed, pigs exhibit high levels of relaxin in ovarian follicular fluids $[8,14]$, and its secretions by corpora lutea and uterine cells significantly increase during the post-ovulatory period $[11,14,16-18]$. 
Numerous studies have reported various actions of relaxin on pig reproductive tissues such as cervical and uterine tissues, including modulation of embryo implantation during pregnancy in rats [19-21]. Despite these physiological conditions, it is not known whether relaxin influences oocyte maturation and/or embryo development in the pig.

Relaxin hormone peptide exerts autocrine, endocrine, and paracrine effects through membrane receptors known as RXFP1 and RXFP2 [22-24]. These receptors have been detected in porcine reproductive tissues [25,26], including oocytes and embryos [27]. But, their potential activation by relaxin and further implications on oocyte maturation and embryo development are still unknown.

From this background, the present study aims to bring more insight into the biological functions of relaxin during early pregnancy using pigs as experimental models. We evaluated the effect of relaxin on the proportion of oocytes resuming nuclear maturation and on embryo development, as well as the total cell number of blastocysts. We determined the effects of relaxin on endogenous relaxin, RXFP1, RXFP2, and pro- (Bax) and anti(Bcl2-like1) apoptotic-related genes expressions in porcine oocytes and in vitro produced embryos.

\section{Methods}

Unless otherwise indicated, all chemicals and reagents were purchased from Sigma-Aldrich (Saint Louis, MO, USA) for embryo production or Invitrogen Co. (Carlsberg, CA, USA) for gene expression. Lyophilised relaxin hormone ( $\mathrm{pRLN}$ ) produced from pregnant sow ovaries was a gift from Dr. C Bagnell [15]. It was dissolved in deionized water $(10 \mu \mathrm{g} / \mathrm{ml})$, aliquoted, and stored as stock solution at $-80^{\circ} \mathrm{C}$. Pre-warmed solutions of $\mathrm{NaCl}$ $(0.9 \% ; \mathrm{w} / \mathrm{v})$ and Hepes-buffered Tyrode Lactate solution (Vigro-Bioniche, Pullman, WA, USA) supplemented with polyvinyl alcohol (PVA: 0.1\%; w/v) and pyruvate $(100 \mu \mathrm{M})$ were used to wash the ovaries, and the oocytes and the embryos, respectively. Oocytes were matured in TCM199+L-glutamine medium supplemented with PVA $(1 \%$; w/v), glucose $(2.8 \mathrm{mM})$, pyruvate (0.91 $\mathrm{mM})$, cysteamine $(0.57 \mathrm{mM})$, EGF $(10 \mathrm{ng} / \mathrm{ml})$, and FSH $(0.4 \mu \mathrm{g} / \mathrm{ml})$ and fertilized in the modified Tris-buffered medium (mTBM) containing caffeine $(2 \mathrm{mM})$ and BSA-fraction V $(0.1 \%$; w/v). Embryos were cultured in NCSU-23 medium (Millipore, Billerica, MA, USA) supplemented with BSA-FAF $(0.4 \%$; w/v). All media contained $10 \mu \mathrm{l} / \mathrm{ml}$ antibiotics (gentamycin and penicillin G/Streptomycin sulphate) and were pre-incubated for at least $2 \mathrm{~h}$ before use. Oocytes and embryos were placed in 4-well dishes (Nunc, Roskilde, Denmark) for incubations under a humidified atmosphere of $39^{\circ} \mathrm{C}$ and $5 \%$ $\mathrm{CO}_{2}$ in air.

\section{Cumulus-oocyte complex collection, in vitro maturation} (IVM), fertilization (IVF) and embryo culture (IVC)

Sow (Yorkshire-Landrace) ovaries were harvested at a local abattoir (Southern Quality Meats, Pontotoc, MS, USA) and washed in the laboratory. Immature cumulusoocyte complexes (COCs) were aspirated from follicles of 3-6 $\mathrm{mm}$ diameter. Oocytes with homogenous ooplasm and surrounded by cumulus cells were selected for maturation per groups of 50-75 COCs in $500 \mu \mathrm{l}$ of medium. After $44 \mathrm{~h}$ incubation, COCs were collected and transferred into $250 \mu \mathrm{l}$ of fertilization medium. High motile spermatozoa of pooled semen (Prestage Farms, West-Point, MS, USA) were purified through a discontinuous percoll gradient (90\%-45\%) and $250 \mu \mathrm{l}$ of suspended sperm cells $\left(12 \times 10^{5}\right.$ spermatozoa/ml $)$ was used to fertilize the COCs. Both gametes were co-incubated (Day 0 post-insemination or Day 0pi). Presumptive zygotes were harvested at $18 \mathrm{hpi}$ and mechanically separated from the cumulus cells followed by the transfer of cumulus free-zygote into drops of cultured medium (1 embryo/1-2 $\mu \mathrm{l}$ ) overlaid with mineral oil. Embryos were incubated for up to 6 days (Day 7pi).

\section{Experiment 1: Developmental and gene expression effects of pRLN added during IVM}

Cumulus-oocyte complexes were matured in the presence of 0,20 or $40 \mathrm{ng} / \mathrm{ml} \mathrm{pRLN}$, or $10 \%(\mathrm{v} / \mathrm{v}) \mathrm{pFF}$. They were subsequently fertilized, and the presumptive zygotes were cultured until the blastocyst stage. All steps were processed as described above.

In a preliminary study aimed at evaluating our culture conditions, a total of $550 \mathrm{COCs}$ (in 4 independent replicates) were matured in the presence of $10 \% \mathrm{pFF}$. Proportions of $44 \pm 4 \%$ (mean \pm SD) cleaved embryos and $17 \pm 3 \%$ (mean $\pm \mathrm{SD}$ ) blastocysts (per cleaved: 40/229) were obtained.

\section{Evaluation of oocyte maturation}

COCs were collected after maturation $(44 \mathrm{~h})$ followed by a mechanical separation of oocytes and cumulus cells. Denuded oocytes were fixed in acetic acid: ethanol $\operatorname{mix}\left(1: 3, \mathrm{v} / \mathrm{v} ; 24 \mathrm{~h}\right.$ at $\left.4^{\circ} \mathrm{C}\right)$, stained with $1 \%$ aceto-orcein' and mounted onto slides for nuclear status evaluation under a phase-contrast microscope (Nikon Instruments Inc.; Melville, NY). Oocytes with germinal vesicle, metaphase I, or metaphase II nucleus features were classified as immature $(\mathrm{GV})$, resuming meiosis (MI), or mature (MII) oocytes.

\section{Evaluation of embryo development}

Proportions of cleaved and blastocyst stage embryos were evaluated on Day 2pi and Day 7pi, respectively.

\section{Sample collection for gene expression}

Groups of 30 immature and 30 mature COCs were mechanically separated from their respective cumulus cells under a stereomicroscope. Isolated cumulus cells 
and cumulus free (or denuded) oocytes and other groups of 10 cleaved embryos (2-4 cells) and 3 blastocysts (Day 7pi) were separately selected under microscope based on morphological criteria (homogenous cytoplasm) for the gene expression study. All samples were stored at $-80^{\circ} \mathrm{C}$ until analysis.

\section{Experiment 2: Developmental and gene expression effects of pRLN added during IVM and IVC}

Cumulus-oocyte complexes were maturated in the presence of 0,20 or $40 \mathrm{ng} \mathrm{pRLN} / \mathrm{ml}$ followed by their fertilization. Resulting zygotes were cultured for up to 6 days (Day 7pi) in the presence of 0,20 or $40 \mathrm{ng} / \mathrm{ml}$ of pRLN. All steps were processed as described above and embryo production was done in duplicate for developmental and gene expression studies.

\section{Developmental evaluation of relaxin effects}

Cleaved and blastocyst stage embryos were recorded on Day 2pi and Day 7pi, respectively. Day 7pi-blastocysts were placed on microscope slides, air dried, fixed (for 24 $h$ in absolute alcohol), and stained with the Hoechst 33342 dye. Blastocyst cell numbers were evaluated under an Epifluorescence microscope (Nikon Inc., Melville, NY, USA).

\section{Sample collection for gene expression}

Groups of 10 zygotes, 10 cleaved (2-4 cells) and 3 blastocyst stage embryos were selected based on their morphology under a stereomicroscope and stored per groups at $-80^{\circ} \mathrm{C}$ until analysis.

\section{RNA isolation and RT-PCR}

Total RNA were isolated from frozen-thawed samples (RNeasy Micro Kit, Qiagen Inc., Valencia, USA), reverse-transcribed into cDNA (Superscription III Platinum ${ }^{\circledR}$ Two-Step qRT-PCR Kit) which were used for detecting the expression levels of relaxin and its receptors (RXFP1 and 2) and apoptotic related genes (Bax and Bcl2-like1). Expression levels of $\beta$-actin in each biological sample were determined for normalization. To this end, semi-quantitative (Taq DNA polymerase kit) and real-time $\left(\mathrm{SYBR}^{\circledR}\right.$ GreenER q PCR SuperMixes for iCycler) PCR techniques were employed. Table 1 summarizes the primer pairs' characteristics. The PCR conditions were as followed: $5 \mathrm{~min}$ at $95^{\circ} \mathrm{C} ; 45$ cycles of [30 sec at $95^{\circ} \mathrm{C}, 30 \mathrm{sec}$ at the optimal annealing temperature (Table 1) and $30 \mathrm{sec}$ at $72^{\circ} \mathrm{C}$ ); $10 \mathrm{~min}$ at $72^{\circ} \mathrm{C}$. Real time PCRs using tested (Bax, Bcl2-like1, Relaxin, RXFP1 and RXFP2) and internal control ( $\beta$-actin) genes' primer pairs were performed, and the comparative $\mathrm{Ct}$ method was used to determine the transcript levels as previously described [28]. Relaxin, RXFP1 and RXFP2 gene expression data are indicated as relative expression to $\beta$-actin, while individually normalized $\mathrm{Bax}$ and $\mathrm{Bcl} 2$ like1 to $\beta$-actin are shown as $\mathrm{Bcl} 2$-like1/Bax ratios. All PCR products were further resolved on $1.5 \%$ agarose gels to verify of the amplification quality given the size of the amplicon products.

In parallel, sections of electrophoresis gels containing relaxin, RXFP1 and RXFP2 PCR products generated from porcine neonates uterine cells (Ut) and ovarian corpora lutea $(\mathrm{CL})$ samples were excised to test their authenticities. Agarose gel sections were purified and submitted for sequencing (BigDye terminator V1.1 cycle sequencing kit; Applied Biosciences Inc., Foster City, USA) followed by their BLAST on pig genome (NCBI repository database). Bax, Bcl2-like1 and $\beta$-actin primer sequences published by Wang et al. were used in this study [28].

\section{Statistical analysis}

All experiments were repeated at least three times and RNA samples obtained from each experimental replicate. One-way ANOVA (SYSTAT, Systat software Inc., Chicago, IL, USA) followed by the Fisher's Least Square Difference test for pairwise comparisons were used to analyze the pRLN effects. The Student's t-test was used to compare the expression levels of Bax, Bcl2-like1,

Table 1 Primer sequence characteristics

\begin{tabular}{|c|c|c|c|c|c|}
\hline \multirow{2}{*}{$\begin{array}{l}\text { Gene symbols } \\
\text { RXFP1 }\end{array}$} & \multirow{2}{*}{$\begin{array}{l}\text { GenBank Acc.\#, } \\
\text { (NCBI) }\end{array}$} & \multicolumn{2}{|c|}{ Primer sequences $\left(5^{\prime}-3^{\prime}\right)$} & \multirow{2}{*}{$\begin{array}{l}\text { AT } \\
\left({ }^{\circ} \mathrm{C}\right)\end{array}$} & \multirow{2}{*}{$\begin{array}{c}\begin{array}{c}\text { Amplicon } \\
\text { sizes (bp) }\end{array} \\
132\end{array}$} \\
\hline & & $\begin{array}{l}\text { S: } \\
\text { AS: }\end{array}$ & $\begin{array}{l}\text { AGGCTGACGAGGACAACT } \\
\text { CAGAACCGACCAAGCATT }\end{array}$ & & \\
\hline RXFP2 & $\begin{array}{l}\text { CA997681.1 } \\
\text { (XM_001927967.1) }\end{array}$ & $\begin{array}{l}\text { S: } \\
\text { AS: }\end{array}$ & $\begin{array}{l}\text { CATCTGCTGGATTCCCGTAT } \\
\text { TTCAAGGCACTGTTCACC }\end{array}$ & 55 & 117 \\
\hline RELAXIN & NM213872.1 & $\begin{array}{l}\text { S: } \\
\text { AS: }\end{array}$ & $\begin{array}{l}\text { TGTGGCTCCGTCTCCTGGGG } \\
\text { GTTGCCTTCAGCTCCTGTGGC }\end{array}$ & 55 & 164 \\
\hline BCL2-like1 & NM214285.1 & $\begin{array}{l}\text { S: } \\
\text { AS: }\end{array}$ & $\begin{array}{l}\text { TGAATCAGAAGCGGAAACCC } \\
\text { GCTCTAGGTGGTCATTCAGGTAAG }\end{array}$ & 60 & 416 \\
\hline BAX & AJ606301 & $\begin{array}{l}\text { S: } \\
\text { AS: }\end{array}$ & $\begin{array}{l}\text { TाTCTGACGGCAACTTCAACTG } \\
\text { AGCCACAAAGATGGTCACTGTCT }\end{array}$ & 60 & 238 \\
\hline$\beta-A C T I N$ & U07786 & $\begin{array}{l}\text { S: } \\
\text { AS: }\end{array}$ & $\begin{array}{l}\text { ACTGGCATTGTCATGGACTCTG } \\
\text { AGTTGAAGGTGGTCTCGTGGAT }\end{array}$ & 60 & 397 \\
\hline
\end{tabular}


RXFP1, and RXFP2 mRNA within the sample type (MCC: mature cumulus cell, or MII: mature oocyte). Results are expressed as mean $( \pm \mathrm{SD})$ for gene expression or $( \pm$ SEM) for developmental data, and $\mathrm{P}<0.05$ are fixed for significant differences.

\section{Results}

Experiment 1: Development and gene expression effects of pRLN added IVM

\section{Developmental effects}

The presence of pRLN during IVM did not affect the cumulus cell expansion (data not shown); however, it did significantly increase the proportion of oocytes that resumed meiosis $(79 \% \pm 4 \%, 87 \% \pm 3 \%$, and $91 \% \pm 3 \%$, for 0,20 and $40 \mathrm{ng} \mathrm{pRLN} / \mathrm{ml}$, respectively, $\mathrm{P}<0.05$ ), and, subsequently, increased the proportions of oocytes that reached metaphase II $(68 \% \pm 5 \%, 80 \% \pm 4 \%$ or $88 \%$ $\pm 4 \%$ for 0,20 or $40 \mathrm{ng} \mathrm{pRLN} / \mathrm{ml}$, respectively, $\mathrm{P}<0.05$; ANOVA; Table 2).

Furthermore, we evaluated the effect of relaxin on embryo development by maturing a total of $1,169 \mathrm{COCs}$ in the presence of 0,20 and $40 \mathrm{ng} \mathrm{pRLN} / \mathrm{ml}$ ( 4 to 7 independent replicates, Table 3). Only $40 \mathrm{ng} \mathrm{pRLN} / \mathrm{ml}$ significantly increased the cleavage and blastocyst rates in comparison to the control group (51 $\pm 5 \%$ and $10 \pm$ $3 \%$ vs. $37 \pm 4 \%$ and $12 \pm 3 \%$, respectively; $\mathrm{P}<0.05$ ). There were no significant differences between the $20 \mathrm{ng}$ $\mathrm{pRLN} / \mathrm{ml}$ treatment and the control. Moreover, the mean cell number of blastocysts was significantly higher in the $40 \mathrm{ng} \mathrm{pRLN} / \mathrm{ml}$ group $(38 \pm 3)$ compared to others (control: $31 \pm 4$ and $20 \mathrm{ng}$ pRLN/ml: $32 \pm 6$; $\mathrm{P}<$ $0.05)$, which appeared similar.

\section{Gene expression effects}

We evaluated the effect of relaxin on Bax, Bcl2-like1, relaxin, RXFP1 and RXFP2 gene expression in both cumulus cells and oocytes. With exception of relaxin, all other gene transcripts were detected in both cell types (Figure 1, 2 and 3). Their expression levels in cumulus cells were always lower than that in oocytes $(\mathrm{P}<0.05)$. The concentration of $40 \mathrm{ng} \mathrm{pRLN} / \mathrm{ml}$ significantly

Table 2 Effect of relaxin on porcine oocyte maturation

\begin{tabular}{ccccc}
\hline $\begin{array}{c}\text { pRLN during } \\
\text { IVM (ng/ml) }\end{array}$ & $\begin{array}{c}\text { Total } \\
\text { Oocytes } \\
\text { (N) }\end{array}$ & \multicolumn{2}{c}{ Nuclear maturation status of oocytes } \\
\hline 0 & 451 & $21 \pm 4(93)^{\mathrm{a}}$ & $11 \pm 5(51)$ & $68 \pm 5(307)^{\mathrm{a}}$ \\
& & & GV\% & \\
20 & 472 & $13 \pm 3(61)^{\mathrm{ab}}$ & $7 \pm 2(31)^{\mathrm{a}}$ & $80 \pm 4(380)^{\mathrm{b}}$ \\
40 & 331 & $9 \pm 3(30)^{\mathrm{b}}$ & $3 \pm 3(9)^{\mathrm{b}}$ & $88 \pm 4(291)^{\mathrm{c}}$ \\
P values (ANOVA) & $10^{-3}$ & 0.03 & $10^{-4}$ \\
\hline
\end{tabular}

${ }^{a b c}$ Different superscripts within the same column indicate significant difference $(P<0.05 ; A N O V A)$. Data are mean values $( \pm S E M)$ of at least 4 independent replicates.
Table 3 Developmental effects of relaxin added during oocyte maturation

\begin{tabular}{|c|c|c|c|c|c|}
\hline \multirow{2}{*}{$\begin{array}{c}\text { pRLN } \\
\text { during IVM } \\
\text { (ng/ml) }\end{array}$} & \multirow{2}{*}{$\begin{array}{c}\text { Total } \\
\text { Zygotes } \\
\text { (N) }\end{array}$} & \multirow{2}{*}{$\begin{array}{l}\text { \% of cleaved } \\
\text { at Day 2pi } \\
\text { (n) }\end{array}$} & \multicolumn{3}{|c|}{$\begin{array}{l}\text { Blastocyst formation at Day } \\
\text { 7pi }\end{array}$} \\
\hline & & & $\begin{array}{c}\text { Total } \\
\text { (T) }\end{array}$ & $\%(\mathrm{~T} / \mathrm{N})$ & $\begin{array}{c}\text { Cell } \\
\text { number (n) }\end{array}$ \\
\hline 0 & 383 & $37 \pm 4(141)^{\mathrm{a}}$ & 45 & $12 \pm 3^{a}$ & $31 \pm 4(16)^{a}$ \\
\hline 20 & 344 & $40 \pm 4(135)^{a}$ & 23 & $8 \pm 4^{a}$ & $32 \pm 6(12)^{a}$ \\
\hline 40 & 442 & $51 \pm 5(226)^{b}$ & 46 & $10 \pm 3^{a}$ & $38 \pm 3(12)^{b}$ \\
\hline
\end{tabular}

${ }^{\mathrm{ab}}$ Different superscripts within the same column indicate significant difference $(P<0.05 ;$ ANOVA $)$. Data are mean values $( \pm$ SEM) of at least 5 independent replicates.

increased RXFP2 mRNA transcript levels in oocytes and cumulus cells (Figure 1A; $\mathrm{P}<0.05$ ), but had no effect on Bcl2-like1/Bax ratios in both cell types (Figure 2). The presence of $10 \%$ porcine follicular fluid (pFF) significantly increased RXFP1 mRNA amounts in mature cumulus cells and oocytes, as well as the Bcl2-like1/Bax ratio in mature oocytes (Figure $1 \mathrm{~B}$ and $2 ; \mathrm{P}<0.05$ ). However, relaxin transcripts were not detected in oocytes, and neither pRLN nor pFF were able to induce its de novo expression (Figure 3A).

\section{Experiment 2: Developmental and gene expression effects of pRLN added during IVM and IVC Developmental effects}

A preliminary study was conducted with a total of 1,343 zygotes cultured in culture media containing 0 (control), 20 , or $40 \mathrm{ng} \mathrm{pRLN} / \mathrm{ml}$. We found no significant effects of relaxin on the proportions of cleaved embryos and blastocysts. However, the mean cell numbers of blastocysts were significantly increased in the presence of pRLN (control: $31 \pm 4,20 \mathrm{ng} / \mathrm{ml}: 49 \pm 12,40 \mathrm{ng} / \mathrm{ml}: 38$ \pm 8 ; $\mathrm{P}<0.05$, ANOVA). Based on these results, we evaluated the effect of pRLN added during oocyte maturation $(0$ or $40 \mathrm{ng} / \mathrm{ml})$ and embryo culture $(0,20$, or 40 $\mathrm{ng} / \mathrm{ml})$.

Oocytes matured in the presence of $40 \mathrm{ng} \mathrm{pRLN} / \mathrm{ml}$ followed the culture of resulting zygotes in the presence of 20 or $40 \mathrm{ng} \mathrm{pRLN} / \mathrm{ml}$ (Treated-1 and Treated-2, respectively). Embryos produced without any exposure to pRLN served as the control group. A total of 949 were used in at least three independent replicates to evaluate the effect of pRLN added during both maturation (Treated-1) and embryo culture (Treated-2). Results summarized in Table 4 revealed a negative effect of pRLN on the cleavage rate in group Treated-1 (40-20) compared to Treated-2 (40-40) and control (33 $\pm 5 \%$ vs. $51 \pm 8 \%$ and $48 \pm 3 \%$, respectively; $\mathrm{P}<0.05)$, whereas no differences in term of blastocysts rates were observed. However, the mean cell number of blastocysts was significantly increased in the Treated-2 group (43 \pm 6) compared to the control group $(31 \pm 3$; $\mathrm{P}<0.05)$. 
A

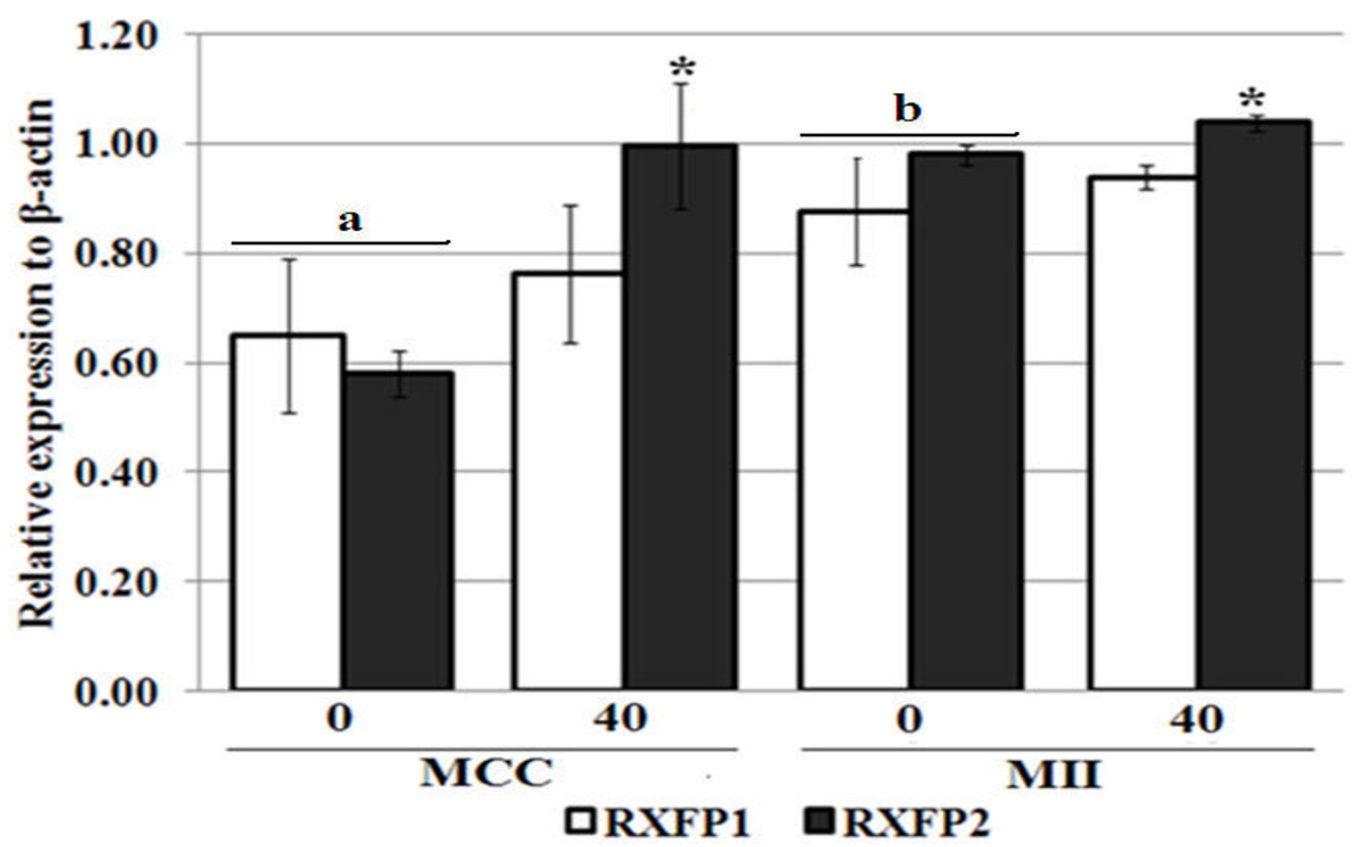

B

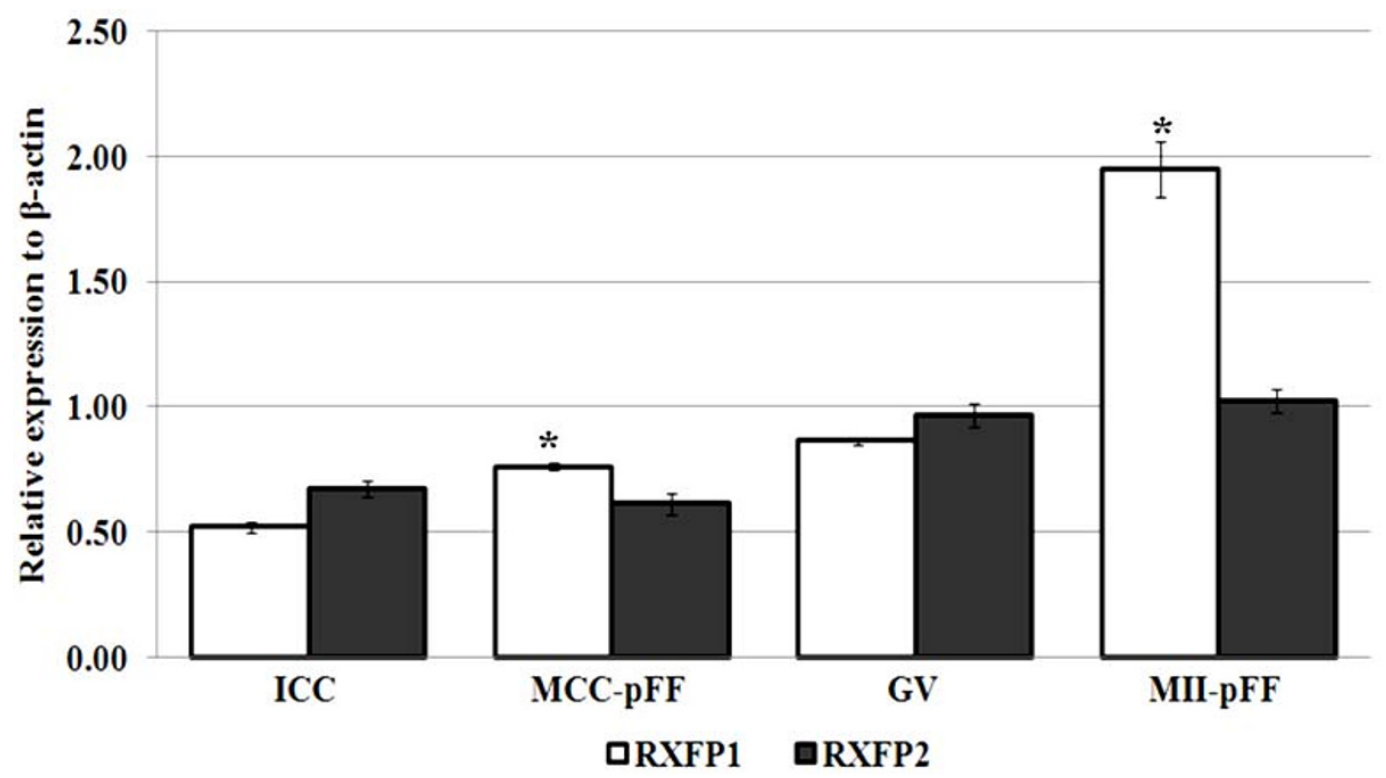

Figure 1 Effect of porcine relaxin (pRLN) and follicular fluid (pFF) on RXFP1 and RXFP2 gene expression in in vitro matured oocyte porcine. Figures represent real-time PCR results of RXFP1 and RXFP2 gene expression in oocytes matured in teh presence of 0 or $40 \mathrm{ng} / \mathrm{ml}$ $\operatorname{pRLN}(\mathbf{A})$, and 0 or $10 \%(\mathrm{~V} / \mathrm{V}) \mathrm{pFF}(\mathbf{B})$. Data are relative expression to their corresponding internal control, $\beta$-actin; and are shown as mean \pm SD of at least three independent replications. Letters $(a, b)$ represent significant differences between immature oocytes and cumulus for both genes, while asterisks $\left(^{*}\right)$ indicate significant differences between treated groups and their corresponding controls within the same gene $(P<0.05$, ANOVA). Immature oocyte and cumulus cells are labelled as GV and ICC, while those that are matured in the presence of pRLN are indicated as MII-40 and MCC-40, or MII-pFF and MCC-pFF for those matured in the presence of pFF. 


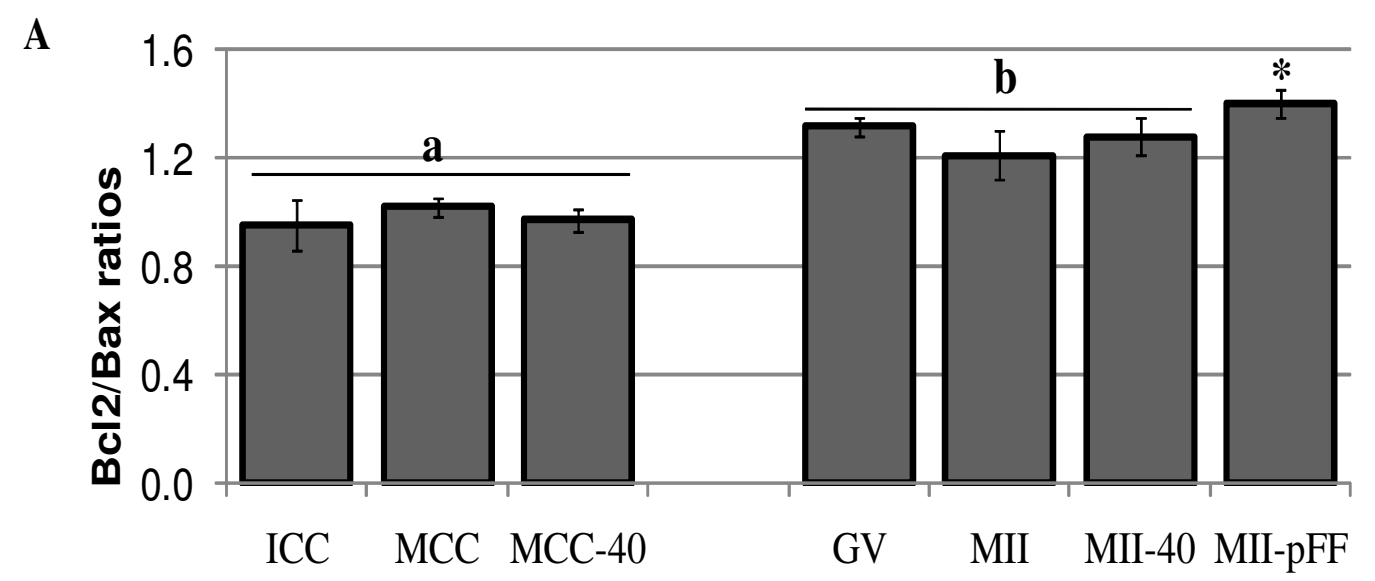

B

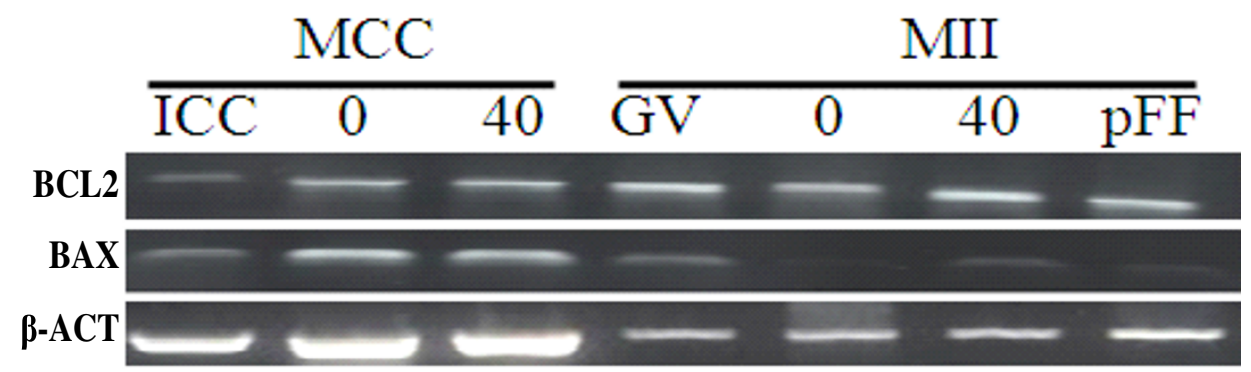

Figure 2 Effect of porcine relaxin (pRLN) and follicular fluid (pFF) on pro- (Bax) and anti-(Bcl2-like 1) apoptotic genes expression in oocytes and cumulus cells. Total RNA were extracted from groups of 30 oocytes and corresponding cumulus cells before and after in vitro maturation in the presence of 0 or $40 \mathrm{ng} \mathrm{pRLN} / \mathrm{ml}$, or $10 \%(\mathrm{v} / \mathrm{V}) \mathrm{pFF}$. Gene expression was assessed using real-time PCR (A) followed by agarose gel electrophoresis of resulted PCR products (B). Analyses were performed in three independent replicates and data were expressed as relative to their corresponding internal control, $\beta$-actin. The figure represents the ratio (mean \pm SD) of individually normalized Bcl2-like1/Bax gene expression. At all stages, oocytes contained significantly higher values than cumulus cells (a,b; $\mathrm{P}<0.05$, ANOVA), and pRLN had no effects on BCl2-like1/Bax ratios (MII-40 and MCC-40), while pFF significantly increased this ratio in oocytes compared to other groups (*; P<0.05, ANOVA). Immature cumulus cells and oocytes are indicated by ICC and GV, respectively. Cumulus-oocyte complexes matured in absence of pRLN are indicated by MCC and MII, corresponding to mature cumulus cells and oocytes. Cumulus cells and oocytes matured in the presence of pRLN are indicated by MCC-40 and MII-40, respectively.

\section{Gene expression effects}

We evaluated the effect of $40 \mathrm{ng} \mathrm{pRLN} / \mathrm{ml}$ added during oocyte maturation (IVM), embryo culture (IVC), or both periods (IVM/IVC) on Bax and Bcl2-like1 gene expression in cleaved and blastocyst stage embryos. Figures $3 \mathrm{~B}$ and $3 \mathrm{C}$ show that the $\mathrm{Bcl} 2$-like1/Bax ratios were significantly higher in cleaved embryos compared to blastocysts $(\mathrm{P}<0.05$, t-test $)$. However, the moment of relaxin exposure (IVM or IVC) had no significant effect on these ratios (ANOVA).

\section{Discussion}

Numerous physiological roles have been attributed to relaxin [10,11]; but its effects during embryo development are still unknown despite its presence in gamete and embryo environments. Here, we could not detect the expression of relaxin in porcine COCs but found an accumulation of its receptors RXFP1 and RXFP2 mRNA in
COCs which appeared to be modulated by exogenous relaxin. In addition, relaxin moderately influenced embryo development but significantly increased the total cell number of blastocysts irrespective of the moment of its addition in the media (oocyte maturation and/or embryo culture).

The present study reports developmental effects of relaxin used at concentrations similar to those found in the literature [29-31]. Indeed, variable but large amounts of relaxin are found in follicular fluids surrounding porcine oocytes, while pre-implantation embryos are suspected to be exposed to unknown amounts of relaxin during their utero-tubal progression and development (corresponding to the ovarian luteal phase). Beneficial roles of relaxin have been demonstrated during follicle growth and ovulation $[7,14]$, uterine receptivity and activity process in various species such as pigs [14], primates [32,33] and rodents [21,34,35]. To our knowledge, the current study is the first to report developmental 


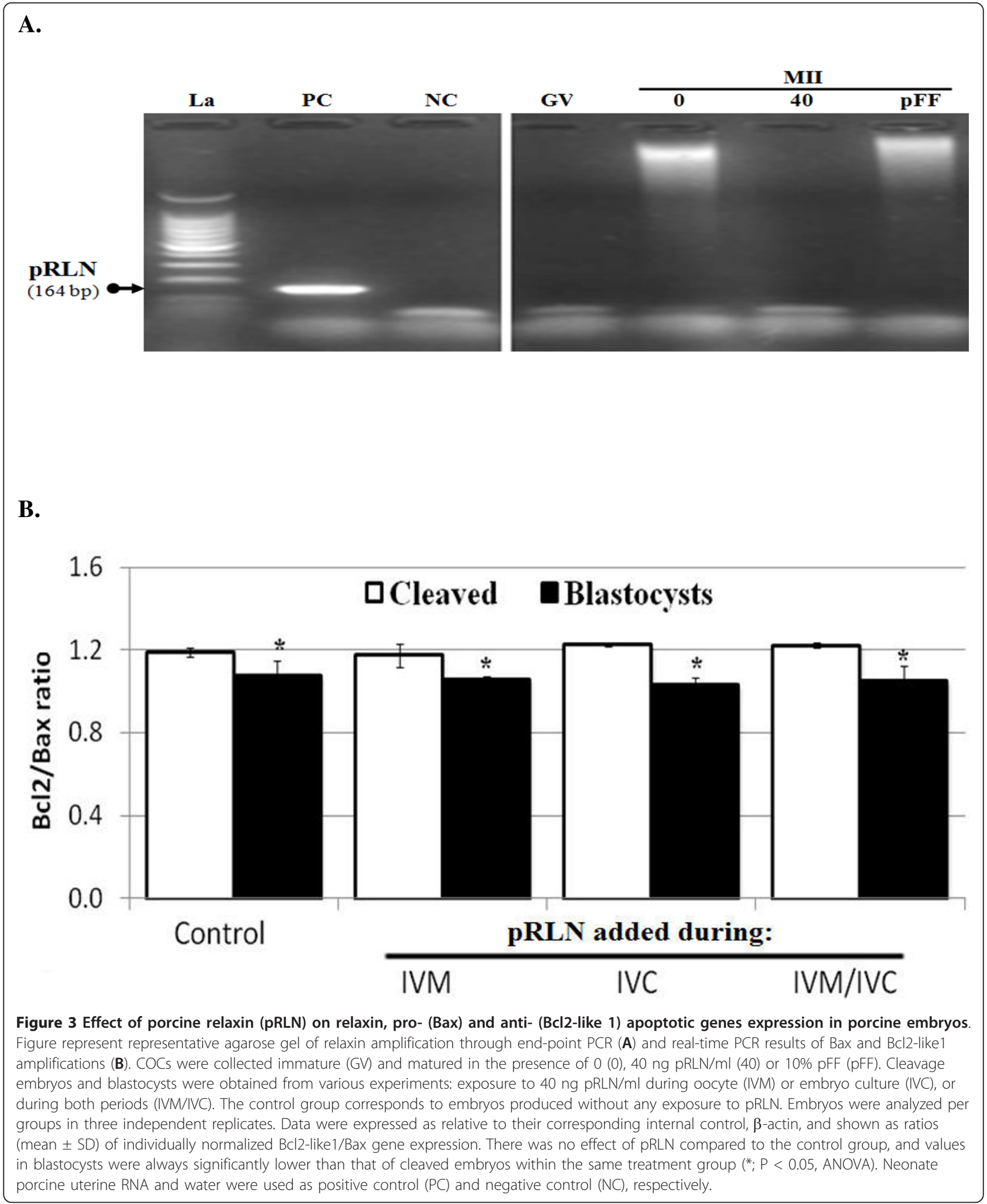


Table 4 Effects of relaxin added during both oocyte maturation and embryo culture

\begin{tabular}{ccccccc}
\hline \multicolumn{2}{c}{$\begin{array}{c}\text { pRLN (ng/ml) during } \\
\text { IVM }\end{array}$} & Total Zygotes (N) & \% of cleaved at Day 2pi (n) & \multicolumn{3}{c}{ Blastocyst formation at Day 7pi } \\
IVC
\end{tabular}

${ }^{\mathrm{abc}}$ Different superscripts within the same columns indicate significant difference $(\mathrm{P}<0.05$; ANOVA). Data are mean values $( \pm$ SEM) of at least 5 independent replicates.

effects of exogenous relaxin during both oocyte maturation and early embryo development.

These effects are results of putative interactions between relaxin and its receptors located on plasma membranes of target cells $[22,24,36]$. In previous studies, we reported the presence of these receptors on porcine oocytes and embryos [27]. Here, we found that the addition of porcine relaxin in a follicular fluid-free maturation medium induces an accumulation of RXFP2 mRNA in COCs. This effect is surprising given that relaxin is the specific ligand of RXFP1, although it can bind with low affinity to RXFP2. This observation suggests a possible role of RXFP2 receptors during mammalian oocyte maturation process in the pig, as also suggested in rhesus macaque [37] and rat [38] oocytes expressing RXFP2 mRNA. In-depth studies of INSL3-RXFP2 complex during oocyte maturation and embryo development will definitely contribute to better characterize the full developmental effects of this complex.

Nevertheless, given the complexity of molecular interactions existing within the follicular fluid, a likely activation of RXFP1 receptors during in vivo oocyte maturation cannot be ruled out; and seems to be highlighted in the current study by the significant increase of RXFP1 mRNA in oocytes matured in the presence of porcine follicular fluid alone. The existence of such interactions may also explain our contradictory results with a recent study reporting a lack of relaxin effect on nuclear maturation of pig oocytes [39]. These authors tested the effect of recombinant human relaxin added in maturation medium already containing porcine follicular fluid $(10 \%)$ and whose high relaxin contents $[8,40]$ and beneficial effect on oocyte maturation $[41,42]$ could have interfered with their results. In our study, oocytes were matured in the absence of follicular fluid, and the supplementation of the basal medium with relaxin significantly increased the proportions of oocytes resuming and accomplishing meiotic maturation. This beneficial effect of relaxin could be explained by its interactions with its receptors leading to an inhibition of oocyte meiosis blocking factors such as cyclic adenosine monophosphate (cAMP) as previously suggested [38].

Most interesting, the developmental effects of relaxin suggest both direct and indirect effects on embryos and oocytes, respectively. While embryos were freed of the surrounding cumulus cells after fertilization, oocytes were matured together with their surrounding cumulus cells. Using rodent oocytes, Kawamura et al. have proposed an indirect effect of relaxin on its targets in a paracrine way [38]. Irrespective of the moment of its addition, the increased total cell number of blastocysts appears as the hallmark of relaxin during early embryo development. Indeed, beneficial effects of relaxin were limited at the cleavage stage (high proportions) following oocyte maturation in the presence of relaxin, while any effects were observed on blastocyst formation compared to the control groups.

Developmental effects of relaxin in our study indicate possible perturbations of molecular mechanisms associated with cell cycle, and specifically cell proliferation. A recent study has demonstrated a positive effect of relaxin on glutathione (GSH) synthesis in in vitro matured porcine oocytes [39]. Indeed, GSH is a routine indicator or oocyte cytoplasmic maturation [43], whose beneficial effects on blastocyst formation and quality (hatching and cell number) are well-documented [44-48]. Therefore, we suggest that the increase of blastocyst cell number in our study is probably associated to an increase of GSH in oocytes and/or developing embryos.

In addition, production of GSH induces an imbalance of reduced-oxidative (REDOX) status of cells leading to potential modifications of cellular functions such as cell cycle (incidence of apoptosis) [49]. Therefore, we anticipated an activation of apoptotic-related genes by relaxin. Apoptosis is an important biological process during blastocyst formation of which fine-tuned balances between pro-apoptotic (Bax) and anti-apoptotic (Bcl2like1) genes are critical for the survival of embryos [50]. Our study revealed that Bcl2-like1/Bax ratios were always in direction of Bcl2-like1 transcripts which is favorable to embryo survival. The presence of relaxin during culture did not significantly affect this ratio which remained comparable between groups.

\section{Conclusions}

In summary, our findings suggest that the increase in the total cell number in blastocysts is the hallmark effect of exogenous relaxin. Given that the cell number of 
blastocysts is an important gauge for in vitro-produced embryos, the supplementation of porcine embryo culture media with relaxin could be considered. However, the effects of relaxin on the expression of developmentally important genes should be investigated.

\section{Acknowledgements}

The authors thank the Southern Quality Meats (Pontotoc, Mississippi, USA) for facilitating the collection of ovaries. This work was supported by the USDA-ARS Biophotonics Initiative project \# 58-6402-3-0120 and the Mississippi Agricultural and Forestry Station (MAFES).

\section{Author details}

'Department of Animal \& Dairy Sciences, Mississippi State University, 4025 Wise Center Dr, Mississippi State, MS 38762, USA. ²Department of Biochemistry \& Molecular Biology, Mississippi State University, 402 Dorman Hall, Mississippi, MS 38762, USA. ${ }^{3}$ Department of Pathobiology \& Population Medicine, Mississippi State University, 240 Wise Center Dr, Mississippi State, MS 38762, USA.

\section{Authors' contributions}

JMF conceived and performed all the experiments, and wrote the first draft of the manuscript. JMG contributed to the in vitro embryo production. STW and PLR contributed to the design of the study, revised and approved the manuscript. All authors read and approved the final manuscript.

\section{Competing interests}

The authors declare that they have no competing interests.

Received: 14 December 2010 Accepted: 27 January 2011

Published: 27 January 2011

\section{References}

1. Kikuchi K, Onishi A, Kashiwazaki N, Iwamoto M, Noguchi J, Kaneko H, Akita T, Nagai T: Successful Piglet Production after Transfer of Blastocysts Produced by a Modified In Vitro System. Biol Reprod 2002, 66(4):1033-1041.

2. Pomar FJ, Teerds KJ, Kidson A, Colenbrander B, Tharasanit T, Aguilar B, Roelen BA: Differences in the incidence of apoptosis between in vivo and in vitro produced blastocysts of farm animal species: a comparative study. Theriogenology 2005, 63(8):2254-2268.

3. Kitagawa Y, Suzuki K, Yoneda A, Watanabe T: Effects of oxygen concentration and antioxidants on the in vitro developmental ability production of reactive oxygen species (ROS), and DNA fragmentation in porcine embryos. Theriogenology 2004, 62(7):1186-1197.

4. Petters RM, Wells KD: Culture of pig embryos. J Reprod Fertil Supp/ 1993 48:61-73.

5. Abeydeera LR: In vitro production of embryos in swine. Theriogenology 2002, 57(1):256-273

6. Webb R, Garnsworthy PC, Campbell BK, Hunter MG: Intra-ovarian regulation of follicular development and oocyte competence in farm animals. Theriogenology 2007, 68:522-\$29.

7. Bagnell CA: Production and biologic action of relaxin within the ovarian follicle: an overview. Steroids 1991, 56(5):242-246.

8. Matsumoto D, Chamley WA: Identification of relaxins in porcine follicular fluid and in the ovary of the immature sow. J Reprod Fertil 1980, 58(2):369-375.

9. Seppala M, Tiitinen A: Endometrial responses to corpus luteum products in cycles with induced ovulation: theoretical and practical considerations. Hum Reprod 1995, 10(Suppl 2):67-76.

10. Hisaw F: Experimental relaxation of the pubic ligament of the guinea pig. Proc Soc Exp Biol Med 1926, 23:661-663.

11. Sherwood OD: Relaxin's physiological roles and other diverse actions. Endocr Rev 2004, 25(2):205-234.

12. Gunnersen JM, Crawford RJ, Tregear GW: Expression of the relaxin gene in rat tissues. Mol Cell Endocrinol 1995, 110(1-2):55-64.

13. Dschietzig T, Bartsch C, Baumann G, Stangl K: Relaxin-a pleiotropic hormone and its emerging role for experimental and clinical therapeutics. Pharmacol Ther 2006, 112(1):38-56.
14. Bagnell CA, Zhang Q, Downey B, Ainsworth L: Sources and biologica actions of relaxin in pigs. J Reprod Fertil Supp/ 1993, 48:127-138.

15. Yan W, Ryan PL, Bartol FF, Bagnell CA: Uterotrophic effects of relaxin related to age and estrogen receptor activation in neonatal pigs. Reproduction 2006, 131(5):943-950.

16. Lobb DK, Porter DG: Rapid increase in relaxin gene expression in early pregnancy in the pig. Mol Cell Endocrinol 1992, 89(1-2):R5-8.

17. Ohleth KM, Bagnell CA: Relaxin secretion and gene expression in porcine granulosa and theca cells are stimulated during in vitro luteinization. Biol Reprod 1999, 60(2):499-507.

18. Parry LJ, Vodstrcil LA: Relaxin Physiology in the Female Reproductive Tract during Pregnancy. Relaxin and Related Peptides 2007, 34-48.

19. Min G, Hartzog MG, Jennings RL, Winn RJ, Sherwood OD: Evidence That Endogenous Relaxin Promotes Growth of the Vagina and Uterus during Pregnancy in Gilts. Endocrinology 1997, 138(2):560-565.

20. Ryan P, Baum D, Lenhart J, Ohleth K, Bagnell C: Expression of uterine and cervical epithelial cadherin during relaxin-induced growth in pigs. Reproduction 2001, 122(6):929-937.

21. Rogers PA, Murphy CR, Squires KR, MacLennan AH: Effects of relaxin on the intrauterine distribution and antimesometrial positioning and orientation of rat blastocysts before implantation. J Reprod Fertil 1983, 68(2):431-435

22. van der Westhuizen ET, Halls ML, Samuel CS, Bathgate RA, Unemori EN, Sutton SW, Summers RJ: Relaxin family peptide receptors-from orphans to therapeutic targets. Drug Discov Today 2008, 13(15-16):640-651.

23. Hayes ES: Biology of primate relaxin: a paracrine signal in early pregnancy? Reprod Biol Endocrinol 2004, 2:36.

24. Bathgate RA, Ivell R, Sanborn BM, Sherwood OD, Summers RJ: International Union of Pharmacology LVII: recommendations for the nomenclature of receptors for relaxin family peptides. Pharmacol Rev 2006, 58(1):7-31.

25. Yan W, Wiley AA, Bathgate RA, Frankshun AL, Lasano S, Crean BD, Steinetz BG, Bagnell CA, Bartol FF: Expression of LGR7 and LGR8 by neonatal porcine uterine tissues and transmission of milk-borne relaxin into the neonatal circulation by suckling. Endocrinology 2006 147(9):4303-4310.

26. Min G, Sherwood OD: Localization of specific relaxin-binding cells in the ovary and testis of pigs. Biol Reprod 1998, 59(2):401-408.

27. Feugang J, Rodriguez-Munoz J, Willard S, Bathgate R, Ryan P: Examination of relaxin and its receptors expression in pig gametes and embryos. Reprod Biol Endocrinol 2011, 9(1):10.

28. Wang H, Rodriguez-Osorio N, Feugang JM, Jung SY, Garrison K, Wolgemuth C, Greer L, Crenshaw M, Memili E: Effects of culture media and inhibitors on biology of porcine early embryonic development in vitro. Livest Sci 2009, 121(1):102-107.

29. Choa SJ, Dlamini BJ, Klindt J, Schwabe C, Jacobson CD, Anderson LL: Antiporcine relaxin (antipRLX540) treatment decreases relaxin plasma concentration and disrupts delivery in late pregnant pigs. Anim Reprod Sci 1998, 52(4):303-316

30. Han YJ, Miah AG, Yoshida M, Sasada H, Hamano K, Kohsaka T, Tsujii H: Effect of relaxin on in vitro fertilization of porcine oocytes. J Reprod Dev 2006, 52(5):657-662.

31. Miah AG, Tareq KM, Hamano K, Kohsaka T, Tsujii H: Effect of relaxin on acrosome reaction and utilization of glucose in boar spermatozoa. $J$ Reprod Dev 2006, 52(6):773-779.

32. Einspanier A, Lieder K, Husen B, Ebert K, Lier S, Einspanier R, Unemori E, Kemper M: Relaxin supports implantation and early pregnancy in the marmoset monkey. Ann N Y Acad Sci 2009, 1160:140-146.

33. Ghosh D, Stewart DR, Nayak NR, Lasley BL, Overstreet JW, Hendrickx AG, Sengupta J: Serum concentrations of oestradiol-17beta, progesterone, relaxin and chorionic gonadotrophin during blastocyst implantation in natural pregnancy cycle and in embryo transfer cycle in the rhesus monkey. Hum Reprod 1997, 12(5):914-920

34. Pusey J, Kelly WA, Bradshaw JM, Porter DG: Myometrial activity and the distribution of blastocysts in the uterus of the rat: interference by relaxin. Biol Reprod 1980, 23(2):394-397.

35. Lee VH, Fields PA: Rabbit endometrial relaxin: immunohistochemical localization during preimplantation, pregnancy, and lactation. Biol Reprod 1990, 42(4):737-745.

36. Halls ML, Bathgate RA, Summers RJ: Relaxin family peptide receptors RXFP1 and RXFP2 modulate CAMP signaling by distinct mechanisms. Mol Pharmacol 2006, 70(1):214-226 
37. Hanna C, Yao S, Patta M, Jensen J, Wu X: Expression of insulin-like 3 (INSL3) and differential splicing of its receptor in the ovary of rhesus macaques. Reprod Biol Endocrinol 2010, 8(1):150.

38. Kawamura K, Kumagai J, Sudo S, Chun SY, Pisarska M, Morita H, Toppari J, Fu P, Wade JD, Bathgate RA, et al: Paracrine regulation of mammalian oocyte maturation and male germ cell survival. Proc Natl Acad Sci USA 2004, 101(19):7323-7328.

39. Kim HS, Jeong YI, Lee JY, Jeong YW, Hossein MS, Hyun HS, Hwang WS: Effects of Recombinant Relaxin on In Vitro Maturation of Porcine Oocytes. J Vet Med Sci 2010, 72(3):333-337.

40. Ohleth KM, Zhang Q, Bagnell CA: Relaxin protein and gene expression in ovarian follicles of immature pigs. J Mol Endocrinol 1998, 21(2):179-187.

41. Avery B, Strobech L, Jacobsen T, Bogh IB, Greve T: In vitro maturation of bovine cumulus-oocyte complexes in undiluted follicular fluid: effect on nuclear maturation, pronucleus formation and embryo development. Theriogenology 2003, 59(3-4):987-999.

42. Marchal R, Feugang JM, Perreau C, Venturi E, Terqui M, Mermillod P. Meiotic and developmental competence of prepubertal and adult swine oocytes. Theriogenology 2001, 56(1):17-29.

43. Luberda Z: The role of glutathione in mammalian gametes. Reprod Biol 2005, 5(1):5-17.

44. de Matos DG, Furnus CC: The importance of having high glutathione (GSH) level after bovine in vitro maturation on embryo development effect of beta-mercaptoethanol, cysteine and cystine. Theriogenology 2000, 53(3):761-771.

45. Feugang JM, de Roover R, Moens A, Leonard S, Dessy F, Donnay I: Addition of beta-mercaptoethanol or Trolox at the morula/blastocyst stage improves the quality of bovine blastocysts and prevents induction of apoptosis and degeneration by prooxidant agents. Theriogenology 2004, 61(1):71-90

46. Furnus CC, de Matos DG, Picco S, Garcia PP, Inda AM, Mattioli G, Errecalde AL: Metabolic requirements associated with GSH synthesis during in vitro maturation of cattle oocytes. Anim Reprod Sci 2008, 109(14):88-99.

47. Van Soom A, Yuan YQ, Peelman LJ, de Matos DG, Dewulf J, Laevens $H$, de Kruif A: Prevalence of apoptosis and inner cell allocation in bovine embryos cultured under different oxygen tensions with or without cysteine addition. Theriogenology 2002, 57(5):1453-1465.

48. Bing YZ, Hirao Y, Iga K, Che LM, Takenouchi N, Kuwayama M, Fuchimoto D, Rodriguez-Martinez HTN: In vitro maturation and glutathione synthesis of porcine oocytes in the presence or absence of cysteamine under different oxygen tensions: role of cumulus cells. Reprod Fertil Dev 2002, 14(3):125-131.

49. Ozawa M, Nagai T, Fahrudin M, Karja NWK, Kaneko H, Noguchi J, Ohnuma K, Kikuchi K: Addition of glutathione or thioredoxin to culture medium reduces intracellular redox status of porcine IVM/IVF embryos, resulting in improved development to the blastocyst stage. Mol Reprod Dev 2006, 73(8):998-1007.

50. Yang M, Rajamahendran R: Expression of Bcl-2 and Bax proteins in relation to quality of bovine oocytes and embryos produced in vitro. Anim Reprod Sci 2002, 70(3-4):159-169.

doi:10.1186/1477-7827-9-15

Cite this article as: Feugang et al: In vitro effects of relaxin on gene expression in porcine cumulus-oocyte complexes and developing embryos. Reproductive Biology and Endocrinology 2011 9:15.

\section{Submit your next manuscript to BioMed Central and take full advantage of:}

- Convenient online submission

- Thorough peer review

- No space constraints or color figure charges

- Immediate publication on acceptance

- Inclusion in PubMed, CAS, Scopus and Google Scholar

- Research which is freely available for redistribution

Submit your manuscript at www.biomedcentral.com/submit
Biomed Central 